\title{
Place in Concomitant Use with Anti- EGFR Radiotherapy in Locally Advanced Head and Neck Cancer Treatment
}

\author{
Anti-EGFR Tedavilerin Lokal Illeri Baş-Boyun Kanserlerinde \\ Radyoterapi ile Eş Zamanlı Kullanımındaki Yeri \\ (1) Meltem Dağdelen ${ }^{1}$, (1) Yüksel Ürün ${ }^{2}$
}

${ }^{1}$ Dr. Ersin Arslan State Hospital, Clinic of Radiation Oncology, Gaziantep, Turkey

${ }^{2}$ Dr. Ersin Arslan State Hospital, Clinic of Medical Oncology, Gaziantep, Turkey

Keywords

Epidermal growth factor receptor inhibitors, radiotherapy, chemoterapy

Anahtar Kelimeler

Epidermal büyüme faktörü reseptörü inhibitörleri, radyoterapi, kemoterapi

Received/Geliş Tarihi : 22.06.2015 Accepted/Kabul Tarihi : 09.12.2015

doi:10.4274/meandros.2349

Address for Correspondence/Yazışma Adresi: Meltem Dağdelen MD,

Dr. Ersin Arslan State Hospital, Clinic of

Radiation Oncology, Gaziantep, Turkey

Phone : +90 5426603810

E-mail : meltemdagdelen@windowslive.com

ORCID ID: orcid.org/0000-0002-2009-0002

(c) Meandros Medical and Dental Journal, Published by Galenos Publishing House.

This is article distributed under the terms of the

Creative Commons Attribution NonCommercial 4.0

International Licence (CC BY-NC 4.0).

\section{Dear Editor;}

Head and neck cancer (HNC) forms $8 \%$ of the adult cancers and each year approximately 600.000 new cases occur. In the course of application, about $40 \%$ of the cases are in early stage, $50 \%$ is locally advanced (stage III and IV) and $10 \%$ is in metastatic stage. More than $90 \%$ of the cases are squamous cell carcinoma and alcohol and smoking are common etiological factors. Human papillomavirus virus is a risk factor especially for oropharyngeal squamous cell carcinoma (1).

The anatomic localization of the disease, the stage of the disease, pathological features and the other diseases of the patient (comorbidity) are important factors to choose the treatment. Although there is not only one approach of treatment, surgical cure and radiotherapy have the similar survival results in early stage. For locally advanced cases, radiotherapy or concomitant chemoradiotherapy is widely used. In concomitant chemoradiotherapy implementations, cisplatin is the gold standard treatment. However, the toxicity related with chemotherapy (particularly cisplatin) restricts the application of chemoradiotherapy with especially the patients who have comorbidity. Epidermal growth factor receptor (EGFR) shows abnormal activity in several epithelial cancers including HNC. Therefore, there are so many done and ongoing studies, which are about different kinds of cancers with the agents who target this pathway (2).

Firstly, in the study of Bonner et al. (3) only radiotherapy (RT) and cetuximab treatments with RT are compared. In combination arm in comparison with only RT, a significantly better local-regional control is statistically provided (median 14.9 months against 24.4 months and $p=0.005$ ). Accordingly, while median survival is 49 months in cetuximab and RT arm for overall survival (OS), it has been found more superior in combination arm as 29.3 months $(p=0.03)$ in RT arm. 
Nevertheless, there are some limitations about this study. In the comparison arm of the study, not using the cisplatin, which is accepted, as a standard today, is a notable disadvantage. Although the number of the patients is not enough to make subgroup analysis, adding cetuximab to the patients who are applied concomitant boost and who have oropharynx disease, is observed to provide more advantages of survival. It should also be taken into consideration that an essential part of the patients included to the study show the features of positive staining with EGFR which is known to have better prognosis (Table 1).

Adding cetuximab to basically cisplatin chemotherapy for the metastatic or relapsed HNC patients in the study "EXTREME" (4) has provided an increase in OS, thus this has risen the interest to EGFR antagonists.
With a later study Radiation Therapy Oncology Group (RTOG) 0522 (5), concomitant cisplatin with $\mathrm{RT}$ and adding cetuximab to RT + cisplatin treatment for stage III-IVB HNC patients are compared. The rates of progression free survival (PFS) and OS are similar in both groups (in order 3 year-PFS 61.2\% and $58.9 \%$ and 3 year-OS $72.9 \%$ and $75.8 \%$ ). Also, a significant difference in local-regional control (LRC) between the two arms cannot be found. According to locoregional failure, any difference is not determined between RT and cisplatin (19.9\%) and RT, cisplatin and cetuximab. Again, any differences have not been observed statistically between both groups in terms of distant metastasis. When p16 evaluation is analyzed, p16 positiveness is determined in 235 out of 321 oropharynx cancer patients. When the patients with p16 expression are compared with the ones without

\begin{tabular}{|c|c|c|c|}
\hline & PFS & OS & LRF \\
\hline Bonner et al. (3) & 2-3 year PFS & 54-month follow up & - \\
\hline RT & $37 \%-31 \%$ & 29.3 month & - \\
\hline RT+Cetuximab & $46 \%-42 \%$ & 49 month & - \\
\hline$p$ & $(p=0.04)$ & $(p=0.03)$ & - \\
\hline RTOG 0522 & 3 year PFS & 3 year OS & 3 year LRF \\
\hline RT+Chemo (Cisplatin) & $61 \%$ & $72.9 \%$ & $19.9 \%$ \\
\hline RT+Chemo+Cetuximab & $58 \%$ & $75.8 \%$ & $25.9 \%$ \\
\hline$p$ & $(p=0.7)$ & $(p=0.3)$ & $(p=0.9)$ \\
\hline CONCERT 1 & 2 year PFS & 2 year OS & 2 year LRF \\
\hline RT+Chemo (Cisplatin) & $65 \%$ & $\% 78$ & $32 \%$ \\
\hline $\mathrm{RT}+$ Chemo+Panitumumab & $61 \%$ & $\% 69$ & $41 \%$ \\
\hline $\mathrm{p}$ & $(p=0.6)$ & $(p=0.1)$ & - \\
\hline CONCERT 2 & 2 year PFS & 2 year OS & LRF \\
\hline RT+Chemo (Cisplatin) & $62 \%$ & $71 \%$ & $38 \%$ \\
\hline RT+Panitumumab & $41 \%$ & $63 \%$ & $53 \%$ \\
\hline Martin et al. (8) & 2 year PFS & - & - \\
\hline RT+Chemo (Cisplatin) & $46 \%$ & - & - \\
\hline $\mathrm{RT}+$ Chemo+Erlotinib & $54 \%$ & - & - \\
\hline $\mathrm{p}$ & $(p=0.7)$ & - & - \\
\hline Rodriguez et al. (9) & 4 year recurrence independent ratio & 4 year OS & - \\
\hline RT+Chemo (5FU+Cisplatin) & $71 \%$ & $69 \%$ & - \\
\hline $\mathrm{RT}+$ Chemo+Gefitinib & $71 \%$ & $66 \%$ & - \\
\hline (Adjuvant continued gefitinib for 2 years) & $(p=0.97)$ & $(p=0.8)$ & - \\
\hline
\end{tabular}


p16 expression, PFS, OS and distant metastasis (DM) of the patients with p16 expression are statistically better. In this study, the superiority of cetuximab to cisplatin cannot be shown except for providing a significant increase of OS with the patients under the age of 50 . When multivariate analysis done in the study, not having p16 expression, N2-3 disease, T4 tumor and low performance are considered as poor prognostic factors. In terms of side effects, significantly more grade 3-4 skin reactions are seen in the group with cetuximab. Radiotherapy toxicity of the arm with cetuximab also increases statistically (Table 1 ).

In the study CONCERT 1 (6) done with another EGFR receptor antagonist panitumumab, RT + cisplatin and $\mathrm{RT}+$ cisplatin + panitumumab are compared in the patient of stage III-IVB HNC (There is no patient with nasopharynx cancer); but there is not seen any differences between two arms in the LRC (two-year LRC in order $68 \%$ and $61 \%$ ). In this study, when the patient group is evaluated additionally in terms of $\mathrm{p} 16$ expression, no differences between the two groups in LRC and PFS are found. While panitumumab increases the skin and mucosa toxicity of the group, both of the groups are similar in terms of febrile neutropenia and renal function disorder (Table 1).

In the study CONCERT 2 (7), cisplatin + RT and panitumumab + RT at the stage III-IVB HNC patients (There is no patient with nasopharynx cancer) are compared and at the LRC, cisplatin arm (61\%) is found to be superior to panitumumab arm $(51 \%)(p=0.03)$. It is seen similar results to the cetuximab study done by Bonner et al. (3) in terms of LRC. When local-regional failure is observed, $53 \%$ local relapse in panitumumab arm and also $38 \%$ local relapse in cisplatin arm are seen. P16 expression of 99 patients is observed in this study and in 24 cases $\mathrm{p} 16(+)$ and in 75 cases $\mathrm{p} 16(-)$ are found. However, when p16(+) and p16(-) patient groups are evaluated separately, the superiority of panitumumab was not be demonstrated. With this study it is clear that panitumumab cannot take the place of cisplatin for the treatment of locally advanced HNC. Furthermore, increased skin toxicity of EGFR inhibitory is also observed (Table 1).

In Martin et al. (8), which is a phase 2 study including erlotinib, the effect of adding erlotinib to cisplatin and $\mathrm{RT}$ is evaluated. The most important difference of this study than the others is this study includes patients with nasopharynx cancer. When toxicity is observed between the two groups, there is a statistical increase of dermatological side-effect (rash) on erlotinib arm. There are not any differences between both arms in terms of other side-effects. Both arms are seen similar in the study in terms of complete response and disease-free survival (DFS). P16 of 90 patients are evaluated and 56 of them are defined as p16(+). Fifty of these patients are oropharynx cancer cases and 6 of them are nasopharynx cancer cases. In oropharynx cancer patients, when $\mathrm{p} 16(+)$ patient group is observed as cisplatin + RT and cisplatin + erlotinib+ $\mathrm{RT}$, the response of the both arms are observed similar. Addition of erlotinib did not make significant difference in complete response in p16 positive patients. However, when both groups are considered, there is statistically significant difference in complete response in $p 16(+)$ patients $(p=0.02)$. The result in this study is similar to RTOG 0522 (Table 1).

Finally, when two studies in which gefitinib is used concurrently are taken into account, gefitinib arm has no more superiority than the other arm statistically when $\mathrm{RT}+$ cisplatin+5 florouracil (5FU) (Arm 1) and RT+gefitinib+cisplatin+5-FU (Arm 2) are compared in Rodriguez et al. (9) study. As the study design is observed, $5 \mathrm{FU}\left(1000 \mathrm{mg} / \mathrm{m}^{2}\right)$ and cisplatin $\left(20 \mathrm{mg} / \mathrm{m}^{2}\right)$ are given as infusion during 4 days in the 1 . and 4 . weeks, and RT fractionation is planned as hyperfractionation. Gefitinib continued as adjuvant chemotherapy for 2 years. In a 4-yearobservation, as RT+cisplatin+5FU (\%88) and $\mathrm{RT}+$ cisplatin+5FU+gefitinib (78\%) are compared in LRC, there is no statistical difference between the groups $(p=0.3)$. Gefitinib arm $(69 \%)$ and the other arm (66\%) are similar for 4-year OS. When this study is evaluated in terms of toxicity, there is a statistical increase of grade 3 and over mucositis, dysphagia and renal function disorder in gefitinib arm. Unlike other studies in this study, the use of hyperfractionated RT is a major disadvantage in terms of early side effects. As it is known, in hyperfractionation RT, total dose is increased by reducing the fraction dose, but this appears to be an increase of early side-effects (Table 1).

Another gefitinib study is the study of Gregoire et al. (10) study, which is phase 2 and double blind. This study is also planned as two phases. Gefitinib is used as concomitant at the first phase as to at the second phase it is used as adjuvant. Seven groups 
are formed in the study, concurrently chemotherapy (cisplatin) +RT+/- gefitinib/placebo and later on as adjuvant gefitinib or placebo treatment are applied to the patients. The superiority of concomitant usage of gefitinib $(32.7 \%)$ against placebo $(\% 33,6)$ cannot be demonstrated in 2 year-LRC. Also in the treatment that is continued as adjuvant, there is no significant difference in LRC ratio between gefitinib (28.8\%) given arm and placebo (37.4\%) given arm. However, as this study is evaluated in terms of toxicity, while there is an increase of diarrhea, rash and grade 3-4 radio-dermatitis, there is no difference in dysphagia and dryness of the mouth in the group where gefitinib is used combined.

Finally, in LUX-Head-Neck 2 (11) study, the study in which the effectiveness of adjuvan afatinib given after RT and chemo is evaluated is still going on. The aim of this study is to compare afatinib given after RT+ chemotherapy as an adjuvant in the stage III-IVB HNC (except for nasopharynx cancer case) patients and placebo. The first end point of the study is DFS.

As a result, when all the studies carried out are evaluated as a whole, if anti-EGFR agents are used with RT, it is not shown any superiority to cisplatin in locally advanced HNCs. On the other hand, they may be useful for the patients who cannot tolerate cisplatin or cannot take cisplatin due to his/her comorbidities.

\section{Ethics}

Informed Consent: Informed consent was not taken since there is no need for one.

Peer-review: Internally peer-reviewed.

\section{Authorship Contributions}

Concept: M.D., Design: M.D., Data Collection or Processing: M.D., Y.Ü., Analysis or Interpretation: M.D., Y.Ü., Literature Search: M.D., Writing: M.D.

Conflict of Interest: No conflict of interest was declared by the authors.

Financial Disclosure: The authors declared that this study received no financial support.

\section{References}

1. GLOBOCAN: Estimated Cancer Incidence and Mortality and Prevalence Worldwide in 2012. Available from: http://globocan. iarc.fr
2. Seiwert TY, Salama JK, Vokes EE. The chemodadition paradigm in head and neck cancer. Nat Clin Pract Oncol 2007; 4: 156-71.

3. Bonner JA, Harari PM, Grialt J, Azarnia N, Shin DM, Cohen RB, Jones $\mathrm{CU}$, et al. Radiotherapy plus cetuximab for squamous-cell carcinoma of the head and neck. N Eng J Med 2006; 354: 567-78.

4. Vermoken JB, Mesia R, Rivera F, Remenar E, Kawecki A, Rottey S, et al. Platinum-based chemotherapy plus cetuximab in head and neck cancer. N Engl J Med 2008; 359: 1116-27.

5. Ang KK, Zhang Q, Rosenthal DI, Nguyen-Tan PF, Sherman EJ, Weber RS, et al. Randomized phase III trial of concurebt accelerated radiation plus cisplatin with or without cetuximab for stage III to IV head and neck carcinoma:RTOG 0522. J Clin Oncol 2014; 32: 2940-50.

6. Mesia R, Henke M, Fortin A, Minn H, Yunes Ancona AC, Cmelak $A$, et al. Chemoradiotherapy with or without panitumumab in patients with unresected, locally advanced squamous-cell carcinoma of the head and neck (CONCERT-1): a randomised, controlled, open-label, phase 2 trial. Lancet Oncol 2015; 16: 20820.

7. Grialt J,Trigo J, Nuyts S, Ozsahin M, Skladowski K, Hatoum G, et al. Panitumumab plus radiotherapy versus chemoradiotherapy in patients with unresected, locally advanced squamous-cell carcinoma of the head and neck (CONCERT-2): a randomised, controlled, open-label phase 2 trial. Lancet Oncol 2015; 16: 22132.

8. Martin RG, Parvathaneni U, Bauman JE, Sharma AK, Raez LE, Papagikos MA, et al. Cisplatin and radiotherapy with or without erlotinib in locally advanced squamous cell carcinoma of the head and neck: a randomized phase 2 trial. J Clin Oncol 2013; 31: 1415-21.

9. Rodriguez CP, Adelstein DJ, Rybicki LA, Saxton JP, Lorenz RR, Wood BG, et al. Single-arm phase 2 study of multiagent concurent chemotherapy and gefitinib in locoregionally advanced squamous cell carcinoma of the head and neck. Wiley Online Library 2011; 34: 1517-23.

10. Gregoire V, Hamoir M, Chen C, Kane M, Kawecki A, Julka PK, et al. Gefitinib plus cisplatin and radiotherapy in previously untreated head and neck squamous cell carcinoma: a phase 2, randomized, double-blind, placebo-controlled study. Radiother Oncol 2011; $100: 62-9$.

11. Burtness B, Bourhis JP, Vermorken JB, Harrington KJ, Cohen EE. Afatinin versus placebo as adjuvant therapy after chemoradiation in double-blind, phase 3 study(LUX-Head\&Neck 2) in patients with primary unresected, clinically intermediate-to-highrisk head and neck cancer:study protocol for a randomized controlled trial. Trials 2014; 15: 469. 